\title{
Forgiveness and politics: Reading Matthew 18:21-35 with survivors of armed conflict in Colombia
}

\begin{tabular}{|c|c|}
\hline \multicolumn{2}{|c|}{$\begin{array}{l}\text { Authors: } \\
\text { Robert W. Heimburger }{ }^{1,2,3} \\
\text { Christopher M. Hays } \\
\text { Guillermo Mejía-Castillo }\end{array}$} \\
\hline \multicolumn{2}{|c|}{$\begin{array}{l}\text { Affiliations: } \\
{ }^{1} \text { Fundación Universitaria } \\
\text { Seminario Bíblico de } \\
\text { Colombia (FUSBC), Colombia }\end{array}$} \\
\hline \multicolumn{2}{|c|}{$\begin{array}{l}{ }^{2} \text { Oxford Pastorate, } \\
\text { United Kingdom }\end{array}$} \\
\hline \multicolumn{2}{|c|}{${ }^{3}$ IFES, United Kingdom } \\
\hline \multicolumn{2}{|c|}{$\begin{array}{l}\text { Corresponding author: } \\
\text { Robert Heimburger, } \\
\text { robert.heimburger@ } \\
\text { oxfordpastorate.org }\end{array}$} \\
\hline \multicolumn{2}{|c|}{$\begin{array}{l}\text { Dates: } \\
\text { Received: } 28 \text { Aug. } 2018 \\
\text { Accepted: } 10 \text { Nov. } 2018 \\
\text { Published: } 19 \text { Feb. } 2019\end{array}$} \\
\hline \multicolumn{2}{|c|}{$\begin{array}{l}\text { How to cite this article: } \\
\text { Heimburger, R.W., Hays, C.M. } \\
\text { \& Mejía-Castillo, G., 2019, } \\
\text { 'Forgiveness and politics: } \\
\text { Reading Matthew 18:21-35 } \\
\text { with survivors of armed } \\
\text { conflict in Colombia', HTS } \\
\text { Teologiese Studies/ } \\
\text { Theological Studies 75(4), } \\
\text { a5245. https://doi. } \\
\text { org/10.4102/hts.v75i4.5245 }\end{array}$} \\
\hline \multicolumn{2}{|c|}{$\begin{array}{l}\text { Copyright: } \\
\text { (C) 2019. The Authors. } \\
\text { Licensee: AOSIS. This } \\
\text { is licensed under the } \\
\text { Creative Commons } \\
\text { Attribution License. }\end{array}$} \\
\hline \multicolumn{2}{|c|}{ Read online: } \\
\hline 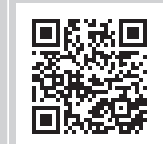 & $\begin{array}{l}\text { Scan this } Q R \\
\text { code with your } \\
\text { smart phone or } \\
\text { mobile device } \\
\text { to read online. }\end{array}$ \\
\hline
\end{tabular}

After decades of armed conflict in Colombia, how do those most affected by that conflict understand forgiveness? While others have researched Colombians' views of forgiveness, this study is the first to do so through discussion of a narrative of forgiveness. Readings of the biblical narrative chosen for this study, the Parable of the Unforgiving Debtor (Mt 18:21-35), can enable North Atlantic scholars to discover dimensions of the parable revealed by those who live lives that mirror the realities of the parable, unlike such scholars. The study aims to understand how conflict survivors, especially internally displaced persons (IDPs), understand forgiveness and its relation to politics. The study also aims to identify how these women and men read Matthew 18:21-35 differently from academics. Groups in eight locations around Colombia discussed Matthew 18:21-35. Researchers led lectura popular de la Biblia [people's readings of the Bible], inviting participants to say how the parable related to their lives and to discuss the political consequences that would come from imitating characters in the parable. Conflict survivors said that forgiving was essential if their communities were going to be communities at all, especially communities at peace, offering freedom and economic opportunity. Unlike commentators, they read Matthew 18:21-35 as enjoining forgiveness towards those beyond their local church and for wrongs involving money and violence. As Colombian churches seek to counter resentment with forgiveness, they should be aware of the power of lectura popular, especially of this parable, to create a safe environment where conflict survivors can speak candidly.

\section{Introduction}

A country of 48 million people, Colombia has suffered from a blighted reputation on the international scene. This is because of its historically entrenched violence, bolstered in the last 40 years by deep ideological polarisation, by lucrative illicit drug trafficking, and by one of the most unequal wealth distributions in the world (ed. Bouvier 2009:xiii). Combined with the proliferation of arms, these factors have produced one of the longest running civil wars in the world. Actors include guerrilla groups from the left, armed groups of vigilantes from the right known as paramilitaries, criminal gangs and military personnel acting against their own people in collusion with the paramilitaries. The outcome of this conflict is forced displacement, with more than 7 million internally displaced persons (IDPs) in Colombia today (Unidad para las Víctimas 2018). This amounts to a humanitarian catastrophe, as hundreds of thousands of families suffer from psychological trauma, intergenerational poverty and political disenfranchisement.

In a setting where conflict has permeated society, forgiveness is needed to end cycles of retribution. Rather than prescribing a vision of forgiveness, the authors wished to hear from those who have survived the conflict about how they understand and experience forgiveness. We wished to discover how forgiveness might serve to forge community among people from different backgrounds, many of whom are living in a new place after experiencing displacement. We also wanted to attend to forgiveness as the starting place for a political life beyond vengeance, embodied in the life of the church. We thought that hearing from conflict survivors by inviting them to discuss a biblical parable about forgiveness would prove more fruitful than asking them direct questions in an interview. While we found published work that interviewed Colombians about forgiveness, we found no such work that uncovered conflict survivors' perspectives on forgiveness by inviting them to interpret and respond to a narrative. Other researchers have also interviewed Colombians about forgiveness, but they asked their participants to respond to cases where victimisers requested forgiveness (López-López et al. 2012, 2013, 2018), they asked direct questions about forgiveness (Castrillón-Guerrero et al. 2018; Cortés et al. 2016) or they analysed how the word perdón [forgiveness] functions in discourse (Roldán et al. 2018). None of these studies invited interlocutors into discussions of narratives about forgiveness. Of those other 
works, only the study by Castrillón-Guerrero et al. (2018) focuses on a population directly affected by the conflict. As such, there is ample room in the literature for reading a biblical parable with conflict survivors, especially IDPs.

In the following, we will explore forgiveness and politics by (1) describing our method, lectura popular de la Biblia [people's readings of the Bible], and (2) recounting how survivors of the armed conflict in Colombia interpret the Parable of the Unforgiving Debtor from Matthew 18:21-35. We present these interpretations in comparison with North Atlantic academics' interpretations of the parable, drawing conclusions about how these conflict survivors understand forgiveness and its relationship to politics. The readings of conflict survivors are fascinating; not only from a readerresponse or theological perspective, but because they illuminate features of the parable that critical commentators from Europe and North America have overlooked.

\section{Method: Lectura popular de Ia Biblia}

To understand forgiveness among survivors of armed conflict ${ }^{1}$ and to enable churches and community groups to facilitate forgiveness, we practiced lectura popular de la Biblia with the Parable of the Unforgiving Debtor (Mt 18:21-35) in several locations across Colombia. This research was conducted as one component of the Fe y Desplazamiento [Faith and Displacement] project based at the Fundación Universitaria Seminario Bíblico de Colombia (FUSBC) in the city of Medellín. In that project, researchers developed relationships with Protestant churches around the country, churches that have displaced persons in their congregations or that serve displaced persons in their communities. Theresearchers worked alongsiderepresentatives of those churches who gathered members of the churches and the communities surrounding those churches to carry out lectura popular as well as other forms of research relating to displacement. Six researchers practiced lectura popular in 11 groups in eight cities, towns or villages, totalling approximately 90 people. This took place from November 2016 to March 2017, just as the agreement between the Colombian government and the FARC guerrilla group was completed and began to be implemented. The locations included the large cities of Bogotá, Medellín and Cartagena; the smaller cities of Granada, Puerto Libertador and Tierralta; and the rural areas of Batata and Piendamó. The groups were made up of predominantly IDPs, except for groups in Tierralta, Granada and the groups at El Libertador in Puerto Libertador. The ethnic make-up varied from Afro-Colombian and mestizo (mixed European and indigenous heritage) in Cartagena to the Nasa indigenous group in Piendamó to mestizo at the other locations. All discussions took place in Spanish. If any of the group members

\footnotetext{
1.As most but not all of our interlocutors experienced forced displacement within Colombia, the term 'internally displaced persons' did not embrace everyone we spoke with. In Colombia, both legislation and individuals who have experienced the harms of war tend to speak of victimas or 'victims', but this term negates the agency of these persons. We choose instead to write about 'conflict survivors' as a loose way of indicating IDPs and others who experienced the worst of armed conflict in Colombia, including a conflict with the Fuerzas Armadas Revolucionarias de Colombi - Ejército del Pueblo (FARC-EP) stretching from 1954 to 2016 and continuing conflicts with the Ejército de Liberación Nacional (ELN) and other armed actors.
}

had been armed actors in the conflict, they did not reveal it to the group, while many revealed that they were victims of armed conflict and violence.

Inspiration for our approach came from the practice of reading the Bible among base ecclesial communities in Latin America as Carlos Mesters and Pablo Richard describe it. The comunidades eclesiais/eclesiales de base [base ecclesial communities] arose from the 1960s onwards to meet for prayer, worship and Bible reading without the direction of the priest. Those involved often live in poverty and exist at the margins of society. Among the activities of these base ecclesial communities is lectura popular de la Biblia, which can be translated as 'people's readings' or 'popular readings of the Bible' and is also called lectura comunitaria [community reading] or lectura pastoral [pastoral reading] (Richard 2003:20). Members gather to 'read the gospel in life', says Mesters (1989:59), discussing a Bible passage alongside events from their lives. As Richard (2003:20) sees it, this process is part of 'returning the Bible to the people of God'. The celebration of marginalised people's readings of Scripture formed an early part of the movement known as liberation theology. Lectura popular de la Biblia bears a close relationship with the movement of Contextual Bible Study that arose in South Africa in the 1980s. As West (1991:174-180, 2011, 2014, 2015) describes and develops it, Contextual Bible Study promotes the critical discussion of biblical texts like the Tamar story in 2 Samuel 13 among marginalised communities to highlight struggle and enable change.

We opted to use lectura popular de la Biblia to listen to Colombian conflict survivors' perceptions of forgiveness while at the same time achieving a fresh hearing of a passage of Scripture. This came out of a sense, firstly, that marginalised men and women live closer to the material reality of the biblical text than do wealthy interpreters from late modern societies (Mesters 1981:203, 206, 1989:8; Ryall, Hodson \& Strine 2017:341-45; Strine 2018). The hope of hearing how people of faith engage with the Bible was a second reason to practice lectura popular de la Biblia (Mesters 1989:55, 75; Richard 2003:21). A final reason for choosing this approach was to learn about forgiveness from those who have suffered through years of armed conflict, for whom forgiveness might be expected to be a more difficult task. While we would not assert that the marginalised have a categorical privilege as readers of Scripture, we agreed that survivors of armed conflict in Colombia share experiences such as precariousness, war, migration and debt with biblical characters that other interpreters of the Bible do not. If, in theological terms, the good news is about the liberation of the oppressed, those who are oppressed not only spiritually but also physically have the ability to see and hear the gospel as good news in a special way. Thus, we wished to listen to the experiences of conflict survivors and to learn how they hear the good news.

The team chose to apply lectura popular de la Biblia to the Parable of the Unforgiving Debtor from Matthew's Gospel (18:21-35), as the pericope provocatively addresses the topic 
of forgiveness, opening up reflection by presenting a story rather than direct moral instruction.

We began each of our readings by inviting the conflict survivor participants to read the parable aloud, asking four different participants to adopt the roles of the narrator, the king, the servant and the companion. Then, we encouraged participants to give their own interpretation of the passage, placing themselves within the story, and mapping the story onto their communities. Sample questions were offered to guide this process, including the following:

- Which character do you identify with in the parable and why?

- Can you identify someone in your community or neighbourhood who acts like the servant whose debt the king forgave? Someone like the companion? The king?

- What political consequences would there be if this community follows the example of the king who forgave his servant?

- What political consequences would there be if this community follows the example of the servant who did not forgive his companion, although the king had forgiven him?

Our use of lectura popular de la Biblia differed from what Mesters (1989:59) describes in one significant respect: we did not suggest that groups read a story from everyday life along with reading a passage of Scripture. Instead, we asked the participants to share stories of people from their own lives who reminded them of the main characters in the parable. This approach bore fruit as participants related an abundance of personal stories about forgiveness. Although our method differed in this way from Mesters' lectura popular de la Biblia, it certainly followed the spirit of lectura popular, drawing discussants into conversation about the Bible in connection with everyday life.

\section{Conflict survivors and scholars read the Parable of the Unforgiving Debtor}

What emerged when we practiced lectura popular de la Biblia with conflict survivors? Their readings of the Parable of the Unforgiving Debtor (Mt 18:21-35) often shed light on aspects of the parable overlooked by critical North Atlantic commentators. Through these readings, those who experience armed conflict in Colombia revealed that they see forgiveness as essential for the well-being of their communities and their country. This section will discuss these results, drawing out points of contact and contrast between these two sets of readers, and allowing our interlocutors' social and political vision of forgiveness to emerge.

\section{Whom to forgive?}

A first contrast between Colombian conflict survivors and North Atlantic academics has to do with the identity of the persons whom the parable exhorts the reader to forgive. Commentators unanimously read the text as an injunction to forgive other members of the community of disciples (see, e.g., Blomberg 1992:281; Deidun 1976:220; France 2007:672; Hagner 1998:536; Konradt 2015:295; Machingura 2010:349; Thompson 1970). ${ }^{2}$ This reading makes good sense if the parable is read within Matthew's fourth discourse (Mt 18:135), the so-called 'Community Discourse' that focuses on relationships among the disciples (Luz 2001:478; Mounce 1991:172; Sabourin 1976:810). ${ }^{3}$

Conflict survivors, however, consistently interpret the passage as requiring forgiveness of people outside of their religious communities. This forgiveness even includes members of armed groups who have committed acts of violence against these conflict survivors and their family members. Fernando Abilio Mosquera-Brand, for example, tells the story of hearing on the phone that his brother had been killed:

I fell to my knees and I said to the Lord, 'Lord, I forgive my brother's murderers. I ask that you forgive them and, Lord, do not permit them to grieve any other Colombian home again. ${ }^{\prime 4}$

Other examples include Sofía's ${ }^{5}$ willingness to forgive her children's murderers, Jerónimo (LPB, Tierralta) forgiving a violent assault, and Sebastián and $\mathrm{Mateo}^{6}$ forgiving a considerable theft. Each of them sees the forgiveness that the parable teaches as applying beyond their own churches.

Although these readings may not fit the immediate literary context of the parable, their approach coheres with teaching previously elaborated in Matthew. A close parallel to Matthew 18:35 arises in the Sermon on the Mount in Matthew 6:14-15:

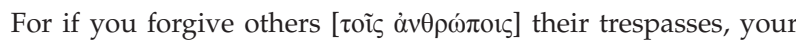
heavenly Father will also forgive you; but if you do not forgive

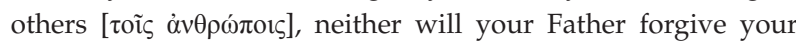
trespasses.

In Matthew 6, however, those to be forgiven are not only

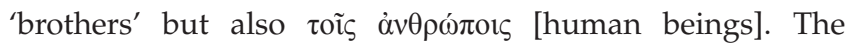
discourse has already commended loving enemies, praying for persecutors and greeting not only one's brothers and sisters (Mt 5:44-47). So, as conflict survivors read the parable as an exhortation to forgive even those outside their religious

2.Blomberg (1992:282) and Bruner (2007:246) countenance a secondary application of the text beyond the confines of the community of believers, while Wiefel of the text beyond the confines of the community of believers, while Wiefel
$(1998: 328)$ argues that the parable was originally meant for a universal audience, and only subsequently circumscribed in application to the community of disciples.

3.See especially Matthew 18:20 ('where two or three are gathered in my name, I am there among them'); also, in the context of the First Gospel, the term 'brothers' typically denotes either consanguinity or membership within the community of disciples (e.g. Mt 12:49-50, 23:8). See also TDNT 1:145; NIDNTT 1:256.

4.Lectura popular de la Biblia [LPB], Cristo Rey, Tierralta, 23 January 2017. Participants: ten men and women. Researcher: Fernando Abilio Mosquera-Brand. Names othe than Mosquera-Brand's have been altered to protect the identities of the subjects.

5.LPB, Santa Viviana, Bogotá, 03 December 2016. Participants: at least seven men and women. Researcher: Milton Acosta-Benítez.

6.LPB, El Libertador, Puerto Libertador, 10 December 2016. Participants: six women and four men. Researcher: Guillermo Mejía-Castillo. 
community, they read Matthew 18 in a way that coheres with the Sermon on the Mount.

\section{Forgiveness for what?}

When academic commentators describe the kinds of offenses that the parable says to forgive, they envision sins that differ dramatically from those that come to mind for survivors of the Colombian civil conflict. Commentators generally explain debt in the parable as an image of a personal offense to forgive (e.g. Blomberg 1992:284; France 2007:703; Hagner 1998:540; Thompson 1970:225). For example, Gnilka (1988:145) lists 'slander, libel, lies, damage, etc.', while conflict survivors mention financial debt, violence, violence because of debt and more.

\section{Money}

Commentators on Matthew do not read the parable as instructing hearers to forgive debts, nor do they relate it to other economic offenses. By illuminating contrast, conflict survivors frequently interpret the parable in an economic sense, as encouraging people to forgive financial debts. For example, Emmanuel ${ }^{7}$, Daniela ${ }^{8}$ and Juan Esteban ${ }^{9}$ relate the parable to times when friends were unable to repay significant personal loans. Others ${ }^{10}$ relate the parable to occasions when customers of a local grocery were unable to pay their tab, the fiado they have run up over time. The owner of a small business, Socorro (LPB, Puerto Libertador, 10 December 2016, G. MejíaCastillo), recounts how a customer owed her money, and from over a wall Socorro overheard this customer demanding money back from yet another person - a striking parallel to the parable. Still others relate the parable to cases of theft (LPB, Puerto Libertador, 10 December 2016, G. Mejía-Castillo).

This dramatic disparity between conflict survivor and academic readings is made all the more intriguing by the fact that commentators spill no small amount of ink attempting to construct a historical account of the financial dynamics at play in the parabolic narrative (Bruner 2007:457-61; De Boer 1988:214-27; Derrett 1970:33-43; Herzog 1994:135-46; Jeremias 1997:236-40; Scott 1985:431-40; Van Eck 2015:5-10). None of the commentators' attention to economic details seems to carry over to their interpretation of the parable's moral significance. Nonetheless, literal debt forgiveness was indeed a component of the ethical exhortation of the historical Jesus (see, e.g., Mt 6:12//Lk 11:4; Lk 4:18-19, 7:40-43, 16:1-13; Oakman 2014; Wright 1996:295; cf. Hays 2010:110-11, 40-46) as a subset of his broader teachings on justice and mercy for the poor (Hays 2013:800-10). The notion of debt forgiveness is at least partially in view in the Lord's Prayer (Mt 6:12; Bazzana

7.LPB, Torre Fuerte, Puerto Libertador, 09 December 2016. Participants: five women and three men. Researcher: Guillermo Mejía-Castillo.

8.LPB, Colegio El Salvador, Cartagena, 26 January 2017. Participants: eight women and three men. Researcher: Guillermo Mejía-Castillo.

9.LPB, Villa Mercedes, Grandeza de Dios, Piendamó, 14 January 2017. Participants: nine men. Researchers: Fernando Abilio Mosquera-Brand and Laura CadavidValencia.

10.LPB, Batata, 22 January 2017. Participants: several men and women. Researcher: Francis Alexis Pineda. Samuel, LPB, Piendamó.
2011:511-25; Drake 2014:233-44; Oakman 2014:42-91), and the details of this parable are explicitly focused on the forgiveness of debts $(18: 27,28)$. While it would be wrong to limit the application of this parable to economic forgiveness, the Matthean literary context and the teachings of the historical Jesus suggest that forgiveness of economic offenses should figure prominently among the applications of the parable (Stassen \& Gushee 2007:363-64). ${ }^{11}$ In this sense, conflict survivors' interpretations encourage New Testament scholars to read the parable in ways that would have resonated more, it seems, with Jesus, the Evangelist and ancient audiences.

\section{Violence}

In a similar manner, survivors of the Colombian conflict apply the parable to their own experiences as victims of violence, as in the case of Pedro ${ }^{12}$ who spoke of forgiving the murders of his mother and brothers. Sofía, too (LPB, Bogotá), says that although she will never forget the suffering caused to her by those who killed and dismembered her children, she would forgive their killers if God gave her opportunity to meet them face to face because she wants her surviving children, grandchildren and great-grandchildren to experience peace. Jerónimo (LPB, Tierralta) says that he not only forgave but sought to protect a man who assaulted him while brandishing a handgun, punching him and hitting him in the testicles for no reason. As someone who lives in a place of guerrilla warfare, Jerónimo shares that, after his assault, a friend returned repeatedly with associates to ask what should be done to the assailant. Even though Jerónimo could not walk for nearly a month, he pleaded with them not to hurt his attacker. Eventually, the assailant was made to leave Tierralta. Jerónimo did not mention police or state actors, and so his choice to forgive meant refusing to escalate armed conflict and opting for an alternative punishment, banishment.

These readings connecting violence and forgiveness encourage scholars to attend to violence when they apply the parable. Commentators recognise the significance of violence in discovering the internal logic of the parable, identifying the injunction to forgive 77 times as an allusion to Lamech's boast that he will avenge violence in Genesis 4:23-24. These scholars agree that the allusion contrasts the unlimited vengeance of Lamech with the unlimited forgiveness that should characterise the community of disciples (see Bonnard 1983:412; Bruner 2007:236; Carson 2004:457-58; Davies \& Allison 1997:792-93; France 2007:705; Lambrecht 1992:55; Manson 1975:212; Mitch \& Sri 2010:234; Mounce 1991:177; Thompson 1970:208). The broader context of Matthew also clearly teaches the disciples to give up violence, even when they have suffered violence (Mt 5:39). Why, then, should the perpetration of violence not be prominent among the offenses which the parable exhorts the reader to forgive?

11.Without connecting the text to economic topics, two commentators draw links to the topic of justice (Schlatter 1929:560; Senior 1987:407), and others connect the passage to mercy, linking Mathew 5.7 and 18.33 but without relating mercy to passage to mercy, linking Matthew 5:7 and 18:33 but without relating mercy to care for the poor or victims of violence (Bruner 2007:241, 243; Castaño Fonseca 2010:406, 408; France 2007:708; Gnilka 1988:148; Grilli \& Langer 2011:481-82; Konradt 2015:295; Hagner 1998:540; Luz 2001:474; Nolland 2005:759-60; Sabourin 1976:823-26).

12.LPB, Batata, 21 January 2017. Participants: ten men and women. Researcher: Fernando Abilio Mosquera-Brand. 
In fact, neither New Testament commentators nor New Testament ethicists list violent offenses among the offenses the parable exhorts the reader to forgive (a literature survey turned up two brief and oblique references to violence, one in a Spanish commentary [Riera i Figueras 2009:228] and the other from Schlatter 1929:561). Two relatively recent articles, not published in journals of biblical scholarship, connect the parable to the topic of domestic violence, arguing against the application of Matthew 18:21-35 to those who have been victims of violence (Illian 2010:444-50; Ramshaw 1998:397404). Similarly, Machingura (2010) argues against the way that religious leaders in Zimbabwe have applied this parable to the violent conflicts suffered in that nation in the previous three decades. The fact that none of these comments are made in biblical commentaries or New Testament journals proves the point that North Atlantic biblical scholarship suffers from a blind spot by failing to relate this parable to matters of violence.

One reason for this blind spot may be that these scholars tend to downplay the gravity of the offenses that the parable urges hearers to forgive. They construe those offenses as trivial because the 100 denarii that the unforgiving debtor demands of his fellow servant pales by comparison to the 10000 talents that he owes to his lord (Blomberg 1992:282; Bruner 2007:238; Davies \& Allison 1997:800; Jeremias 1997:237; Pilch \& Malina 1993:87; Turner 2008:450-51). As 100 denarii would have equalled 100 days' wages for a Palestinian peasant (cf. Mt 20:116), this amount still would be a significant debt. In overlooking the significance of this debt, scholars' attention might be focused on offenses that are pettier than the violent acts dealt with in the parable and in conflict survivors' experiences.

\section{Money and violence}

Conflict survivors' readings bring out another element ignored even by the few scholars who address this parable's relationship with violence: the connection between money and violence. In their interpretation of the parable, those who have lived through conflict (LPB, Batata, 21 January 2017) explain that people often hire local thugs to attack their debtors if the debtors cannot repay. Three women (LPB, Bogotá) who were forced to leave their homes and who settled in Bogotá describe how the pagadiarios - local loan sharks who charge exorbitant interest rates and expect daily or weekly payments - brutalise or kill those who fail to repay sums as small as 20000 pesos (US\$6-7). In both these scenarios, the speakers explained that the parable teaches them to eschew the use of bloodshed in order to recover debts.

Another account from a conflict survivor that links money, violence and forgiveness comes in the remarkable story of Sebastián (LPB, Puerto Libertador, 10 December 2016, G. Mejía-Castillo). Sebastián shares that he and his business partner Mateo bought four heifers, but then they discovered that those heifers had been stolen. Puerto Libertador, Sebastián says, is an area where this kind of thing is not forgiven. It turned out that Carlos, the young man who sold them the cows, had stolen them from Carlos' own grandmother, but Carlos had already spent the money, and so returning the cows to Carlos' grandmother would have amounted to a loss for Sebastián and Mateo. Carlos was brought to them, and Mateo 'wanted immediate vengeance and justice', in Sebastián's words. Carlos was tied up to be killed, but Sebastián said that he did not agree with hurting him, that he forgave the young man and that he was ready to lose the money. Mateo, who was not a Christian, said, 'Man, if you do it, then I'll do it too.' They returned the animals, and the two partners accepted the monetary loss without retaliating, even though they lived in a place where a group was ready to settle these kinds of disputes. Sebastián says that God has blessed him, and Carlos is still alive 3 years later. But there is a twist: Sebastián and Mateo told Carlos that if he wanted to live, he had to behave differently and leave the area.

Sebastián's story represents a robust sort of forgiveness. He and Mateo agree to set the wrong aside rather than meting out an extrajudicial killing. Still, in setting that wrong aside, there are consequences, and Sebastián and Mateo banish the thief, Carlos, from the area. When Sebastian proposes to forgive Carlos, his forgiveness is infectious, revealing the 'domino effect' that Mariana in Granada ${ }^{13}$ identified: if someone seeks to be paid for a debt, another person will seek payment, and so on; but if someone forgives, the next person forgives. In this case, forgiveness represents a break from civil conflict rather than simply an exchange between two individuals. In a setting where state actors are not mentioned, forgiveness is not simply a vehicle for personal healing and transformation; it is an improvised way of preventing killing and keeping a community together. Sebastián's case answers the concerns of those who responded to presentations of this research in academic settings in Bogotá and Medellín with concerns that forgiveness means giving up on justice. Instead, Sebastian's forgiveness is a different form of justice, marked by de-escalation rather than perpetuation.

These same dynamics of money, violence and forgiveness are present in the parable, as New Testament scholars sometimes note in their historical explanations of the text, although they never bridge the gap to the moral application of the parable. In the story, the unforgiving debtor seizes his fellow servant by the neck when demanding repayment of the 100 denarii debt (Mt 18:28). ${ }^{14}$ Likewise, the king punishes the unforgiving debtor by handing him over to torturers until his debt is repaid (Mt 18:34; cf. Bruner 2007:461; Davies \& Allison 1997:802-03; France 2007:708; Jeremias 1997:239; Luz 2001:474). The experience of debt among wealthy Western commentators has little to do with a fear of violence, but for those who experience conflict and displacement, as for people in the first century, money and violence are bedfellows.

\section{The political consequences of forgiveness}

Having laid out these points of discontinuity between conflict survivors' readings and academic commentators' interpretations of Matthew 18:21-35, we wish to discuss the

13.LPB, Salón del Nunca Más, Granada, 10 March 2017. Participants: several men and women. Researcher: Robert W. Heimburger.

14.For further detail, see Derrett (1970:46-47) and Jeremias (1997:239). 
robust vision of forgiveness as a political phenomenon that conflict survivors offer. For most North Atlantic commentators, this is a parable that exhorts members of Christian communities to forgive one another for personal offenses, usually trivial ones. For conflict survivors, however, this is a parable that teaches forgiveness of people outside the church, even one's own enemies, for all manner of major economic offenses and even the most brutal acts of violence. Given their far more expansive interpretation of this text, conflict survivors used it as an occasion to sketch a dramatic socio-political vision. When the researchers asked about the political consequences for the community if the community imitates the unforgiving debtor or the king, those who experienced conflict in Colombia agreed: not only is forgiveness essential for a peaceful community; it is essential for the very possibility of community.

When asked what it would look like for a community if people act like the unforgiving debtor, Paula Andrea (LPB, Bogotá) explains that such greed and non-forgiveness would produce polarisation and breed violence:

'Well, the rich would get richer and the poor would get poorer, speaking politically. In practice, politics is power, money ... Few people think about the community. So it would be the rich getting richer and the poor getting poorer and there would be violence in the lower-income communities ... There would be violence, insecurity, and everything; everything derives from that (i.e. acting like the unforgiving debtor).'

Likewise, María Fernanda (LPB, Tierralta) says that by acting like the unforgiving debtor, Colombia will return to violence. When asked what will happen if Tierralta does not forgive the paramilitaries, guerrillas, criminal bands (bacrim) and common criminals, she says that children will grow up with resentment, starting new armed groups to satisfy their desire for revenge.

However, conflict survivors say that acting like the king and forgiving debts would bring sweeping change to their communities. On some accounts, this change starts with individual acts of forgiveness that have wide implications. Santiago ${ }^{15}$, for example, describes his slow movement away from vengeance. After his brother was stabbed in the stomach, he tracked the killer for 4 years, but he never found the man. One morning before dawn, Santiago arrived at the murderer's parents' house, but he thanks God who gave him the wisdom to see that they were not at fault. He says, 'I came to understand that there were many better things to live for than vengeance'. Javier (LPB, Piendamó), a member of the Nasa indigenous group, begins with a story of forgiving his brother that he connects to freedom and peace for Colombia. He says that a fight with his brother left him angry, and he left the area, but he knew he lacked freedom, and his brother was 'affected psychologically'. Four years later, Javier returned to forgive his brother, and Javier felt 'completely women and two men. Researcher: Milton Acosta-Benítez. free. ... I believe that forgiving is how one achieves true peace, the peace that we need here in Colombia'. Likewise, Pedro (LPB, Batata, 21 January 2017) says that 'forgiveness liberates, and ... if in Colombia people forgive, I say that Colombia will be liberated'.

Others who endured conflict reveal the economic dimension of the parable when asked about the consequences for their communities of acting like the unforgiving debtor. Says Alexander (LPB, Tierralta):

'A town ... will not prosper because hate and rancour bring with them envy and other negative attitudes which will cause the town's progress and prosperity to stagnate. Our town will always be in ruins. It will not be a town that attracts enterprise, industry, or markets to the town because we will have an attitude of vengeance. ... It would be a town that stagnates economically, and there would be no progress.'

On the other hand, Laura Sofía (LPB, Bogotá) says that forgiving like the king will bring greater economic equality, resulting in a decrease in violence:

'If there were people who [acted] like the rich man who forgave the servant's debt, [there would be] political consequences. ... Everything would be more equal, and there would be less suffering, less poverty, and above all, less violence.'

Representing a choice between conflict and peace, economic ruin and opportunity, acting like the unforgiving servant or like the king has wide implications for community cohesion, say, conflict survivors. Valentina (LPB, Puerto Libertador, 09 December 2016) says that if people in her community imitated the unforgiving servant, as her mother would say, 'everything would turn into porridge' ('todo se volvería una mazamorra'). When her group laughs, she explains that she is speaking about what would happen 'if I hit, and you hit me,' and the hitting goes on. Another group (LPB, Tierralta) says that forgiving like the king will lead to refreshment, joy, clear vision and community well-being. In Medellín, too, the contrast is strong. Acting like the servant, says Natalia ${ }^{16}$, means that there will be violence like in the war they lived through, with shootings day and night. She continues: ' 10,20 , 30 dead bodies. The dog's dead, the cat's dead, the neighbour's dead. The male neighbour's dead and the female neighbour's dead. You step over the corpses.' But other members of the group say that if those in the community act like the king, there would be compassion, peace and understanding. No one would have to go hungry or sleep on the sidewalk: there would be daily bread.

In Cartagena, the choice for forgiveness or lack of forgiveness is a choice both ultimate and mundane. It is a choice between heaven and hell; if we were 'like the king, look, [we would be] happy, we would be in glory', says Valeria (LPB, Cartagena). On another level, it is about whether local people will cooperate as activists and give out of their own pocketbook to seek the good of the neighbourhood, says Juliana (LPB, 16.LPB, Granizal, Medellín, 28 January 2017. Participants: four women. Researcher: Guillermo Mejía-Castillo. 
Cartagena). Andrés (LPB, Cartagena) contrasts a place where one neighbour confronts another with a handgun with a place where people forgive like the king and pick up a neighbour's trash, where one neighbour helps another repair a wall:

'When a neighbour gets furious over any little thing and comes at you with a machete, with a revolver, with whatever, then forgiveness is far off, it's far off. If we were to forgive everyone's mistakes, if even on your street, everyone forgave, then everyone would live in harmony and everyone would live in peace. Then, if a neighbour needed to fix up a wall, "Neighbour, here we are; let's do it". Nobody would stop this street, this barrio [neighbourhood], because the people would be united.'

The conflict survivors who held this expansive vision of the political consequences of forgiveness were also asked whether they knew people in their communities who forgive magnanimously like the king. In many of the groups, members identified people in their communities who resemble the forgiving king as well as others who resemble the servant. We were intrigued to note that all respondents who were able to identify people who are like the king reside in smaller towns or rural areas (LPB, Batata; Granada; Puerto Libertador, 09 December 2016; Puerto Libertador, 10 December 2016, G. Mejía-Castillo; Puerto Libertador, 10 December 2016, M. Acosta-Benítez; Tierralta). In three groups made up primarily of IDPs in the large cities of Bogotá, Medellín and Cartagena, the participants said that they know someone around them who acts like the servant, a character who is forgiven but fails to forgive others, but they cannot name people in their communities who are like the king. It appears that conflict survivors in metropolitan areas have less acquaintance than those in towns and villages with people who forgive large debts or great wrongs.

Still, those who experienced the violence and displacement of conflict in Colombia share a common vision. To forgive or not to forgive is a choice between picking up trash or not, between living in safety or stepping over dead bodies, between children forming new armed groups or children working in new businesses. To forgive or not to forgive is a choice between peace and war, between community and lack of community, between letting live and killing, between life in glory and life in hell.

\section{Two caveats and a reflection}

In highlighting the voices of conflict survivors who commend forgiveness as the way to peace, economic well-being and community, we do not want to overlook the pitfalls of extolling forgiveness. In separate articles, Ramshaw, Illian and Machingura strenuously object to interpreting Matthew 18:21-35 in a way that does not require that earnest repentance precedes the extension of forgiveness. While each of these scholars gives exegetical arguments for this reading, they are also motivated by ethical concerns relating to violence: domestic violence in the case of Ramshaw (1998:398) and
Illian (2010:450) and violent civil conflict in Zimbabwe in the case of Machingura (2010:351,353). These scholars argue that teaching repeated and unconditional forgiveness apart from repentance could foster the continued perpetration of violence by agents who have never been obliged to recognise and make restitution for their wrongdoing. Ramshaw (1998:403-04) opines that in applying Matthew 18:22, power dynamics ought to be taken into account so that the more vulnerable party should not be required to forgive the offenses of a stronger, violent abuser. This is a poignant observation, given the well-known concern of Jesus and the Synoptic authors to favour the vulnerable over against the powerful, and given the fact that the Community Discourse begins with injunctions to imitate and protect 'these little ones' (Mt 18:1-6). When we presented this research to university and seminary audiences in Colombia's largest cities, Bogotá and Medellín, this same concern was among the first they expressed.

In highlighting the voices of conflict survivors, the authors do not wish to ignore the victimisers' responsibility for repentance and restoration. To minimise this responsibility would direct forgiveness towards deepening social injustice, a concern that Ramshaw, Illian and Machingura are right to raise. Nor should anything said here be taken as naively orchestrating or manipulating the liberating instrument that forgiveness represents to perpetuate or validate the victimisers' abuses. The forgiveness that this lectura popular of Matthew 18:21-35 has revealed should never be understood or applied without respecting and protecting the vulnerability of survivors of the armed conflict.

Still, the voices of those survivors need to be taken seriously when they argue for the necessity of forgiveness. They argue this for three reasons: firstly, because their sins have been forgiven by Jesus' death on the cross (LPB, Medellin; Piendamó); secondly, because failure to forgive will damage them spiritually (LPB, Batata, 22 January 2017; Cartagena) or socially (LPB, Cartagena; Tierralta); and thirdly, because such forgiveness is vital for their own emotional and spiritual flourishing (LPB, Batata, 21 January 2017; Medellín; Piendamó). Although caution is crucial, such caution should not be used to turn away victims from the liberating, healing power of forgiveness in the contagious and unconditional form that many of our conversation partners exhibited. One of these was Juan Esteban (LPB, Piendamó), the indigenous IDP, who said, 'When we reached out our hands [of forgiveness], we were set free'.

As an additional caveat, it is not the purpose of this discussion to fault the New Testament guild for interpreting this text in a manner that is relevant to their social and historical contexts. Rather, we wish to show how conflict survivors, because of their unique experiences, poverty and sufferings, are attentive to elements of the text that are overlooked by North Atlantic commentators and yet are more coherent with the moral vision of the First Gospel as a whole. 
Reflecting on the strengths and limitations of this approach, using lectura popular de la Biblia enabled us to listen to and highlight the views of those who we might have assumed would have difficulty forgiving, Colombian conflict survivors. The open-ended nature of the discussion allowed the participants to share at length about their experiences and their views of forgiveness. Still, different views on forgiveness and politics might have arisen by seeking out current or former members of armed groups, and this could be a fruitful future line of enquiry. Also, pairing discussions of forgiveness with discussions of justice could have addressed the concerns of Ramshaw, Illian and Machingura more extensively. Indeed, the next stage of Fe y Desplazamiento is doing just that, as we have created curricula to use at churches and among IDPs that draw them into parallel discussions about justice and forgiveness.

We believe that lectura popular de la Biblia, particularly of Matthew 18:21-35 as discussed above, exhibits great potential to counter the effects of ideological polarisation in Colombian society at large and in the churches. In today's Colombia, the churches are strategically positioned to promote forgiveness and address deep-running resentment. There is a significant opportunity for the churches to use lectura popular de la Biblia of this Matthean passage to create a safe and healing environment for the survivors of the armed conflict, allowing them to speak candidly.

\section{Conclusion}

The interpretive advantages of Colombian conflict survivors prime them to generate new exegetical insights as well as an expansive sociopolitical vision based on Matthew 18:21-35, a passage that North Atlantic commentators tend to interpret as instructions merely about life within the community of the local church. At an exegetical level, conflict survivors draw out features of the Matthean text that are overlooked by North Atlantic biblical scholars. But at a political and theological level, the testimony of conflict survivors that emerges through lectura popular reveals the dramatic potential of this parable to stimulate the political imagination of an abused population that those in political and religious power have often disenfranchised and ignored. They envision a forgiveness that brings peace, economic opportunity, freedom, and community. These conflict survivors tell us that forgiveness offered beyond one's religious community for all kinds of offenses, including financial and violent offenses, is the route to the peace dearly needed in a country marred by three generations of civil conflict. As Emmanuel told us, 'There would be communion, a happy harmony ... There would never be conflicts if we lived like the king, forgiving one another' (LPB, Puerto Libertador, 09 December 2016).

\section{Ethical considerations}

In order to ensure the safety and anonymity of participants in this research, all participant names have been replaced with pseudonyms. The research protocol was developed with the participation and consultation of national researchers and approved by the FUSBC Research Ethics Committee. Care was taken to ensure that the topics explored in the focus groups would not retraumatise participants, and in most instances, a trained psychological professional was available in the event that participants required attention following the experience. All participants gave their informed consent prior to participating in the study by completing written permission forms. Along with a written explanation of the research, in order to account for low levels of literacy, the researchers gave the participants an oral explanation of the nature and purposes of the study and the participants' rights in relation to the study. Focus group interviews took place in safe locations where privacy was ensured. The researchers completed the 'Protecting Human Research Participants' certification of the US National Institutes of Health.

\section{Acknowledgements}

This project was made possible through the support of a grant from the Templeton World Charity Foundation (TWCF).

The authors thank Fernando Abilio Mosquera-Brand, Milton Alfonso Acosta-Benítez, Francis Alexis Pineda, and Laura Cadavid-Valencia, who along with G.M.C. and R.W.H. carried out the fieldwork. The authors also thank those who commented on early versions of this article at presentations in Berlin, Oxford, Boston, Medellín, and Bogotá, especially David López-Amaya.

\section{Competing interests}

The opinions expressed in this article are those of the authors and do not necessarily reflect the views of TWCF or the Fundación Universitaria Seminario Bíblico de Colombia (FUSBC).

\section{Authors' contributions}

R.W.H. conceived the research plan. R.W.H. and C.M.H. analysed the data, and R.W.H., C.M.H. and G.M.C. wrote the article. C.M.H. served as principal investigator for $\mathrm{Fe} y$ Desplazamiento (Faith and Displacement), a research project of the Fundación Universitaria Seminario Bíblico de Colombia (FUSBC) of which this publication forms a part.

\section{References}

Bazzana, G.B., 2011, 'Basileia and debt relief: The forgiveness of debts in the Lord's Prayer in light of documentary papyri', Catholic Biblical Quarterly 73, 511-525.

Blomberg, C.L., 1992, Matthew, Broadman, Nashville, TN.

Bonnard, P., 1983, Evangelio según San Mateo, transl. P.R. Santidrian, 2nd edn., Cristiandad, Madrid.

Bouvier, V.M. (ed.), 2009, Colombia: Building peace in a time of war, United States Institute of Peace Press, Washington, D.C.

Bruner, F.D., 2007, Matthew: A commentary, revised edn., Eerdmans, Grand Rapids, MI. Carson, D.A., 2004, Comentario bíblico del expositor: Mateo, transl. R. Acosta, Vida, Miami.

Castaño Fonseca, A.M., 2010, Evangelio de Marcos; Evangelio de Mateo, Verbo Divino, Estella.

Castrillón-Guerrero, L., Riveros Fiallo, V., Knudsen, M.L., López-López, W., Correa-Chica, A. \& Castañeda Polanco, J.G., 2018, 'Comprensiones de perdón, reconciliación y justicia en víctimas de desplazamiento forzado en Colombia', Revista de Estudios Sociales 63, 84-98. https://doi.org/10.7440/res63.2018.07 
Cortés, Á., Torres, A., López-López, W., Pérez, D.C. \& Pineda-Marín, C., 2016 'Comprensiones sobre el perdón y la reconciliación en el contexto del conflicto 'Comado colombiano', Psychosocial Intervention 25(1), 19-25. https://doi. armado colombiano', Psychoso

Davies, W.D. \& Allison, D.C., 1997, A critical and exegetical commentary on the Gospel according to Saint Matthew, T\&T Clark, Edinburgh.

De Boer, M.C., 1988, 'Ten thousand talents? Matthew's interpretation and redaction of the parable of the unforgiving servant (Matt 18:23-35)', Catholic Biblical Quarterly 50, 214-232.

Deidun, T., 1976, 'The parable of the unmerciful servant (Mt 18:23-35)', Biblical TheologyBulletin6(2-3),203-224.https://doi.org/10.1177/014610797600600305

Derrett, J.D.M., 1970, Law in the New Testament, Darton, Longman and Todd, London.

Drake, L., 2014, 'Did Jesus oppose the prosbul in the forgiveness petition of the Lord's prayer?', Novum Testamentum 56, 233-244. https://doi.org/10.1163/15685365 12341447

France, R.T., 2007, The Gospel of Matthew, Eerdmans, Grand Rapids, MI.

Gnilka, J., 1988, Das Matthäusevangelium, Herder, Freiburg.

Grilli, M. \& Langer, C., 2011, Comentario al Evangelio de Mateo, Verbo Divino, Estella. Hagner, D.A., 1998, Matthew 14-28, Word, Dallas, TX.

Hays, C.M., 2010, Luke's wealth ethics: A study in their coherence and character, Mohr Siebeck, Tübingen.

Hays, C.M., 2013, 'Rich \& poor', in J.B. Green, J.K. Brown \& N. Perrin (eds.), Dictionary of Jesus and the Gospels, revised edn., pp. 800-810, IVP Academic, Downers Grove, IL.

Herzog, W.R., 1994, Parables as subversive speech: Jesus as pedagogue of the oppressed, Westminster/John Knox, Louisville, KY.

Illian, B., 2010, 'Church discipline and forgiveness in Matthew 18:5-35', Currents in Theology and Mission 37(6), 444-450.

Jeremias, J., 1997, Las parábolas de Jesús, 11th edn., Verbo Divino, Estella, Navarra.

Konradt, M., 2015, Das Evangelium nach Matthäus, Vandenhoeck \& Ruprecht, Göttingen.

Lambrecht, J., 1992, Out of the treasure: The parables in the Gospel of Matthew, Peeters, Louvain.

López-López, W., Pineda Marín, C., Murcia León, M.C., Perilla Garzón, D.C. \& Mullet, E., 2012, 'Colombian lay people's willingness to forgive different actors of the armed conflict: Results from a pilot study', Psicológica: Revista de Metodología y Psicología Experimental 33(3), 655-663.

López-López, W., Pineda Marín, C., Murcia León, M.C., Perilla Garzón, D.C. \& Mullet, E., 2013, 'Forgiving perpetrators of violence: Colombian people's positions', Social Indicators Research 114(2), 287-301. https://doi.org/10.1007/s11205-012-0146-1

López-López, W., Sandoval Alvarado, G., Rodríguez, S., Ruiz, C., León, J.D., Pineda Marín, C. et al., 2018, 'Forgiving former perpetrators of violence and reintegrating them into Colombian civil society: Noncombatant citizens' positions', Peace and Conflict: Journal of Peace Psychology 24(2), 201-215. https://doi.org/10.1037/ pac0000295

Luz, U., 2001, Matthew 8-20: A commentary, transl. J.E. Crouch, Fortress, Minneapolis, $\mathrm{MN}$.

Machingura, F., 2010, 'The reading \& interpretation of Matthew 18:21-22 in relation to multiple reconciliations: The Zimbabwean experience', Exchange 39(4), 331354. https://doi.org/10.1163/157254310X537016

Manson, T.W., 1975, The sayings of Jesus, SCM, London.

Mesters, C., 1981, 'The use of the Bible in Christian communities of the common people', transl. J. Drury, in S. Torres \& J. Eagleson (eds.), The challenge of basic Christian communities: Papers from the International Ecumenical Congress of Theology, February 20-March 2, 1980, São Paulo, Brazil, pp. 197-210, Orbis Books, Maryknoll, NY.
Mesters, C., 1989, Defenseless flower: A new reading of the Bible, transl. F. McDonagh, Orbis, Maryknoll, NY.

Mitch, C. \& Sri, E., 2010, The Gospel of Matthew, Baker Academic, Grand Rapids, MI.

Mounce, R.H., 1991, Matthew, Baker, Grand Rapids, MI.

Nolland, J., 2005, The Gospel of Matthew: A commentary on the Greek text, Eerdmans, Grand Rapids, MI.

Oakman, D.E., 2014, Jesus, debt, and the Lord's Prayer: First-century debt and Jesus' intentions, Cascade, Eugene, OR.

Pilch, J.J. \& Malina, B.J., 1993, Biblical social values and their meaning: A handbook, Hendrickson, Peabody, MA.

Ramshaw, E.J., 1998, 'Power and forgiveness in Matthew 18', Word \& World 18(4), 397-404.

Richard, P., 2003, ' 40 años de la teología de la liberación en América Latina y el Caribe (1962-2002)', Documentos del Ocote Encendido 25, 4-27.

Riera i Figueras, F., 2009, El evangelio de Mateo: El dificil consenso en una iglesia plural (Mt 3-20), Sal Terrae, Santander.

Roldán, C.A.R., Cortés, M.P.Z., García, P.A.R., Tarazona, J.A. \& García, S.G., 2018, 'Representaciones sociales de estudiantes universitarios acerca de la palabra "perdón" en el contexto del conflicto y postconflicto colombiano', Cambios y Permanencias 9(1), 562-592.

Ryall, A., Hodson, J. \& Strine, C.A., 2017, 'Everybody knows: Engaged research and the changing role of the academic', Participations: Journal of Audience \& Reception Studies 14(1), 329-350.

Sabourin, L., 1976, /l Vangelo di Matteo: Teologia e esegesi, new edn. augmented, Edizioni Paoline, Marino.

Schlatter, A., 1929, Der Evangelist Matthäus: Seine Sprache, sein Ziel, seine Selbstständigkeit: Ein Kommentar zum ersten Evangelium, Calwer Verlag, Stuttgart.

Scott, B.B., 1985, 'The king's accounting: Matthew 18:23-34', Journal of Biblical Literature 104(3), 429-442. https://doi.org/10.2307/3260923

Senior, D., 1987, 'Matthew 18:21-35', Interpretation 41(4), 403-407.

Stassen, G.H. \& Gushee, D.P., 2007, La ética del reino: Siguiendo a Jesús en un contexto contemporáneo, transl. S. Fricke, Mundo Hispano, El Paso, TX.

Strine, C.A., 2018, 'The study of involuntary migration as a hermeneutical guide for reading the Jacob narrative', Biblical Interpretation 26, 485-498.

Thompson, W.G., 1970, Matthew's advice to a divided community: Mt. 17,22-18,35, Biblical Institute Press, Rome.

Turner, D.L., 2008, Matthew, Baker Academic, Grand Rapids, MI.

Unidad para las Víctimas, 2018, Registro único de víctimas, viewed 09 July 2018, from https://www.unidadvictimas.gov.co/es/registro-unico-de-victimas-ruv/37394

Van Eck, E., 2015, 'Honour and debt release in the parable of the unmerciful servant (Mt 18:23-33): A social-scientific and realistic reading', HTS Teologiese Studies/ Theological Studies 71(1), e1-e11. https://doi.org/10.4102/hts.v71i1.2838

West, G.O., 1991, Biblical hermeneutics of liberation: Modes of reading the Bible in the South African context, Cluster Publications, Pietermaritzburg.

West, G.O., 2011, 'Do two walk together? Walking with the other through contextual bible study', Anglican Theological Review 93(3), 431-449.

West, G.O., 2014, 'Locating "Contextual Bible Study" within biblical liberation hermeneutics and intercultural biblical hermeneutics', HTS Teologiese Studies/ Theological Studies 70(1), e1-e10. https://doi.org/10.4102/hts.v70i1.2641

West, G.O., 2015, 'Reading the Bible with the marginalised: The value/s of contextual Bible reading', Stellenbosch Theological Journal 1(2), 235-261. https://doi. org/10.17570/stj.2015.v1n2.a11

Wiefel, W., 1998, Das Evangelium nach Matthäus, new edn., Evangelische Verlagsanstalt, Leipzig.

Wright, N.T., 1996, Jesus and the victory of God, SPCK, London. 